\title{
Den problematiske forskjellen
}

Hjemmerespiratorbehandling har vært brukt i mer enn 60 år (1). For noen grupper, særlig pasienter med langsomt progredierende nevrologiske sykdommer og andre relativt stabile ekstrapulmonale tilstander, er det en godt dokumentert effekt av slik behandling på overlevelse og livskvalitet. Mye tyder på at dette gjelder også andre pasientgrupper der holdningen har vært mer restriktiv, for eksempel amyotrofisk lateral sklerose (ALS) (2). Tollefsen og medarbeidere ved Nasjonalt kompetansesenter for hjemmerespiratorbehandling publiserer i dette nummer av Tidsskriftet interessante data vedrørende bruk av hjemmerespirator i Norge (3). Fra 2002 til og med 2007 mottok 133 barn og 1149 voksne slik behandling, de fleste gjennom maske. Snaut halvparten av de voksne hadde enten kronisk obstruktiv lungesykdom eller adipositas, mens de fleste andre voksne og de aller fleste barna hadde respirasjonssvikt forårsaket av nevrologisk sykdom.

Det mest oppsiktsvekkende funnet i undersøkelsen er de store regionale forskjellene når det gjelder prevalens av hjemmerespiratorbehandling. Hos barn var slik behandling nesten tre ganger mer brukt i Helse Nord enn i Helse Sør-Øst. Hos voksne var behandlingen nesten tre ganger så vanlig i Helse Nord som i Helse MidtNorge. Store regionale forskjeller når det dreier seg om livsforlengende og livskvalitetshevende terapi, bryter med idealet om likebehandling. Årsakene til disse forskjellene er ikke kjent, men de skyldes neppe geografiske variasjoner i sykdomspanorama. Nærhet til behandlingsapparatet kan ha betydning, men forklarer neppe den høye bruken i Nord-Norge sammenliknet med Østlandet, der folk gjennomgående bor nærmere sykehus. Det er derfor mer sannsynlig at lokale ildsjeler har bidratt til at både holdninger og praktisk medisin utvikler seg annerledes i enkelte områder enn i andre (4). Innen nevrologien har det vært en utbredt holdning at livskvaliteten til personer med amyotrofisk lateral sklerose er så lav at respiratorbehandling er etisk forkastelig. Denne holdningen tilbakevises av forskning (2) og er sannsynligvis i endring.

Hjemmerespiratorbehandling er i mange tilfeller svært kostbart, og behandlingen kan ha store konsekvenser både for overlevelse og livskvalitet. Fra et etisk perspektiv er store regionale forskjeller problematiske - enten disse gjenspeiler at nordlendinger får formålsløs respiratorbehandling eller at østlendinger ikke mottar den hjelpen de kunne ha fått. I begge tilfeller er andre forhold enn godt faglig skjønn avgjørende for hvem som får tilbud om behandling. Eksempler på slike forhold kan være kjennskap til at behandlingstilbudet overhodet finnes og hvilken nytteverdi det har samt kapasitet og kompetanse ved sykehus og i hjemmetjeneste. Fra vår egen praksis har vi sett at man i enkelte bydeler i Oslo gir et glimrende pleie- og omsorgstilbud til pasienter med amyotrofisk lateral sklerose med stor grad av funksjonssvikt, mens man i andre bydeler er langt mer restriktive med å innvilge hjemmesykepleie og andre omsorgstjenester. Dette påvirker sannsynligvis pasientenes ønske om livsforlengende behandling. Legens holdninger og evne til å formidle adekvat informasjon påvirker også pasientens mulighet til å si ja eller nei til slik behandling på objektivt grunnlag.

Regionale forskjeller i bruk av kostbar behandling gjelder ikke bare hjemmerespiratorbehandling. Tilsvarende forskjeller har for eksempel vært rapportert for bruk av kostbar immunmodulerende behandling ved multippel sklerose (5). Det er viktig at forskjellene avdekkes. Snarere enn å utløse en skyttergravskrig der vi forsvarer praksisen i våre respektive helseregioner, bør vi prøve å avdekke de underliggende årsakene til forskjellene og enes om felles retningslinjer. Dette er viktig både for å gi den enkelte pasient optimal behandling og for å sikre at helseressursene utnyttes optimalt. Det nasjonale kompetansesenteret bør ta initiativ til at et slikt arbeid settes i gang. I arbeidet med retningslinjer må etiske aspekter samt brukererfaringer inkluderes.

Nasjonalt kompetansesenter for hjemmerespiratorbehandling har bygd opp et nettverk av medarbeidere i alle helseregioner. Kombinert med et nasjonalt register er dette er en interessant løsning som i seg selv kan bidra til mer enhetlig praksis ved at det er kontakt mellom sentrale fagpersoner. En slik organisering kan imidlertid være ressurskrevende. Kompetansesenteret bør derfor dokumentere at anvendelsen av hjemmerespiratorbehandling virkelig harmoniseres og optimaliseres $i$ årene som kommer.

Forskning på positive og negative sider ved hjemmerespiratorbehandling er nødvendig for å utarbeide gode retningslinjer. Dette gjelder særlig ved raskt progredierende nevrologisk sykdom, der nytteverdien er dårligst dokumentert. Her inngår kartlegging av konsekvensene av behandlingen for de pårørende samt hvilken betydning moderat kognitiv svikt har for pasientens evne til å forstå konsekvensene for seg selv og sine nærmeste. Også de faglige, etiske og helseøkonomiske utfordringene som hjemmerespiratorbehandling utgjør for kommunehelsetjenesten bør kartlegges. Liberal bruk av dyr behandling er ikke nødvendigvis etisk høyverdig dersom ressursene kunne vært brukt bedre. Livsforlengende hjemmerespiratorbehandling av pasienter med stort pleiebehov er svært ressurskrevende. I slike tilfeller utgjør den medisinske behandlingen og spesialisthelsetjenestens innsats en liten andel av den totale ressursbruken på pleie og omsorg. Hjemmerespiratorbehandling kan derfor ikke vurderes isolert eller utelukkende som en del av spesialisthelsetjenesten - nytten av og omkostningene ved behandlingen må veies opp mot annen behandling i et bredt perspektiv.

\section{Trygve Holmøy}

trygve.holmoy@rr-research.uio.no

Reidun Førde

reidun.forde@medisin.uio.no

Trygve Holmøy (f. 1960) er postdoktorstipendiat ved Immunologisk institutt ved Universitetet i Oslo og overlege ved Nevrologisk avdeling ved Oslo universitetssykehus, Ullevål, der han har drevet ALS-poliklinikken siden 1997.

\section{Reidun Førde (f. 1950) er lege og professor i medisinsk etikk ved Universitetet} iOslo.

\section{Oppgitte interessekonflikter: Ingen}

\section{Litteratur}

1. Duiverman ML, Bladder G, Meinesz AF et al. Home mechanical ventilatory support in patients with restrictive ventilatory disorders: a 48-year experience. Respir Med 2006; 100: 56-65

2. Radunovic A, Mitsumoto H, Leigh PN. Clinical care of patients with amyotrophic lateral sclerosis. Lancet Neurol 2007; 6: 913-25.

3. Tollefsen E, Gulsvik A, Bakke P et al. Prevalens av hjemmerespiratorbehandling i Norge. Tidsskr Nor Legeforen 2009; 129: 2094-7.

4. Swensen E. Hverdagshelt med maske. Tidsskr Nor Lægeforen 2006; 126: 794-5.

5. Torkildsen 0, Grytten N. Myhr KM. Immunomodulatory treatment of multiple sclerosis in Norway. Acta Neurol Scand Suppl 2007; 187: 46-50. 